\title{
PROTEKSI DINI ANAK TERHADAP SISI NEGATIF MEDIA SOSIAL Abdulloh Arif Mukhlas
}

STAI Al-Azhar Menganti

\begin{abstract}
Along with the rapid development of technology, the mentality of the Islamic generation has become a big homework for every parent and educator. Not only to form a mental ready to face technological advances, but also to form a generation capable of responding to, selecting and transforming technological advances into Islamic learning media. The stages of life's journey illustrate that in character building, the provision of learning material and the giving of freedom to make choices also have adjustment stages. The period of the period when children are not able to distinguish positive and negative ones for themselves, are still weak in controlling their desires, it is not right to be allowed to determine their life choices. Likewise, it is not right to be given the freedom to plunge into the illusion of a life full of badness even though there are also many good things, because it has great potential in making wrong choices. The formation of good thoughts and habituation of actions are the main principles in Islamic education to fortify oneself in living freedom of thought and freedom of association. The sense of feeling that is formed due to the habit of doing good will make a person tend to choose good and leave evil even though they do not know the legal basis.
\end{abstract}

Keywords: Children, Technology, Social Media

\begin{abstract}
Abstrak
Seiring dengan pesatnya perkembangan teknologi, mentalitas generasi Islam menjadi PR besar bagi setiap orang tua maupun para pendidik. Bukan sekedar membentuk mentalnya yang siap menghadapi kemajuan teknologi, namun juga membentuk generasi yang mampu untuk mensikapi, memilih dan mentransformasi kemajuan teknologi menjadi media pembelajaran yang Islami. Tahapan perjalanan kehidupan memberikan gambaran bahwa dalam pembentukan karakter, pemberian materi pembelajaran maupun pemberian kebebasan menentukan pilihan juga memiliki tahapan penyesuaian. Masa periode anak yang belum mampu membedakan positif dan negatif untuk dirinya, masih lemah dalam mengendalikan nafsunya, tidak benar jika dibiarkan menentukan pilihan hidupnya. Demikian juga tidak benar jika diberikan kebebasan terjun dalam ilusi kehidupan yang penuh dengan keburukan meskipun juga terdapat banyak kebaikan, karena memiliki potensi besar dalam salah menentukan pilihan. Pembentukan pemikiran dan pembiasaan perbuatan yang baik adalah asas utama dalam pendidikan Agama Islam untuk membentengi diri di dalam menjalani kebebasan pemikiran dan kebebasan pergaulan. Citra rasa yang terbentuk karena kebiasaan berbuat baik akan menjadikan seseorang cenderung memilih kebaikan dan meninggalkan kejahatan meskipun belum mengetahui dasar hukumnya.
\end{abstract}

Kata Kunci: Anak, Teknologi, Media Sosial

Program Studi Pendidikan Guru Madrasah Ibtidaiyah

STAI Al-Azhar Menganti Gresik, Indonesia

Pendahuluan (Font Times New Roman, Ukuran 12pt, spasi 1,5)

Banyaknya lembaga pendidikan yang menimbulkan satu kebingungan tersendiri bagi orang tua dalam menentukan pilihan terbaik untuk masa depan anaknya. Setiap lembaga menawarkan keunggulan yang dimiliki, menunjukkan kelebihannya dan menutupi kekurangannya, demi untuk menarik simpati masyarakat. Kebijakan apapun yang dipilih oleh sebuah lembaga pendidikan, ada alasan yang menguatkan bahwa kebijakan tersebut sematamata untuk kebaikan dan kemajuan peserta didiknya. Sekalipun kebijakan tersebut jelas bertentangan dengan kebijakan yang diambil oleh lembaga pendidikan yang lain. Karena pada dasarnya setiap sesuatu selalu memiliki sisi baik dan sisi buruk, dan terdapat metode 
ZAHRA: Research And Tought Elmentary School Of Islam Journal Vol. (1) (2), (Agustus)(2020), (Halaman)(68-77)| 69 untuk mendapatkan sisi baiknya yang beragam, sehingga butuh keahlian untuk tetap mempertahankan nilai kebaikan dan mengarahkan sisi buruknya menjadi sebuah kebaikan. Dari sisi lain pertimbangan kebaikan yang mengarah kepada tujuan pendidikan Islam juga tidak boleh diabaikan. Yang utama adalah tercapainya esensi dari tujuan pendidikan Islam, meskipun konsep dan metodenya berbeda. Misalnya, terdapat perbedaan kebijakan sebagian lembaga pendidikan dalam mensikapi positif dan negatifnya media sosial. Sebagian membolehkan siswanya memanfaatkan media sosial dalam pengawasan. Namun oleh sebagian lembaga yang lain lebih cenderung melarang siswa mengakses media sosial, karena banyak memuat hal-hal yang sifatnya tidak mendidik.

Sudah menjadi pengakuan secara umum bahwa pesatnya perkembangan media sosial juga membawa sisi negatif, hususnya bagi anak-anak. Menurut Menteri Yohana, sisi positif dari penggunaan media sosial adalah sebagai sarana yang memuat banyak ilmu pengetahuan untuk belajar, dan juga sebagai sarana komunikasi. Namun diantara sisi negatifnya adalah ketergantungan dan kecanduan yang bisa mempengaruhi otak anak-anak. Lebih parahnya lagi jika anak sudah terpapar informasi dan konten yang tidak layak seperti pornografi.

Merujuk pada survey Asosiasi Penyelenggara Jasa Internet Indonesia (APJII) diketahui jumlah pengguna internet di Indonesia sudah mencapai 143,26 juta. Dari jumlah tersebut, pengguna internet anak usia 13-18 tahun berjumlah 16,68\% atau 24,35 juta anak yang mengakses internet di Indonesia. Sehingga Kementerian Pemberdayaan Perempuan dan Perlindungan Anak (Kemen PPPA) menyelenggarakan Sosialisasi Internet Cerdas Bagi Anak di Wardo, Distrik Biak Barat, Kabupaten Biak Sebagai upaya pencegahan dan proteksi dini terhadap pengaruh negatif internet bagi anak (Siaran Pers Nomor: B- 180/Set/Rokum/MP 01/10/2018). Dari paparan fenomena dan konteks tersebut, maka banyak masalah yang muncul dan perlu mendapat perhatian untuk dilakukan pendalaman. Namun untuk lebih fokus dan mendalam dalam pembahasannya, penulisan ini dibatasi dan fokus pada bagaimana proteksi dini anak terhadap sisi negatif media sosial dalam pendidikan agama Islam. Tujuan yang ingin dicapai dalam penelitian ini adalah untuk menemukan dan mendeskripsikan tentang bagaimana pendidikan agama Islam memberikan proteksi terhadap anak dalam menghadapi perkembangan sosial media yang memiliki banyak sisi negatif dan juga memuat banyak sisi positif.

\section{Metode Penelitian}

Penulisan ini dilakukan dengan metode penelitian kualitatif. Penelitian yang menggambarkan fenomena secara holistik, dari data yang dihasilkan melalui observasi, wawancara dan dokumentasi 
ZAHRA: Research And Tought Elmentary School Of Islam Journal Vol. (1) (2), (Agustus)(2020), (Halaman)(68-77)| 70 yang berupa kata-kata maupun laporan terinci dari pandangan subyek maupun informan dan melakukan studi pada situasi yang dialami (Creswell, 1998:15). Penelitian kualitatif ini akan menghasilkan data deskriptif berupa kata-kata tertulis, lisan dari subyek dan informan dan juga perilaku yang terjadi. Penelitian yang memandang fenomena secara holistik, dilakukan dalam kondisi alamiah yang bersifat penemuan atau eksplorasi dan menetapkan peneliti sebagai instrumen, serta melakukan analisa data secara induktif.

\section{Hasil Penelitian}

\section{Pengertian Pendidikan Islam}

Pendidikan Islam dapat diartikan sebagai usaha mengoptimalkan potensi manusia sesuai dengan statusnya, berdasarkan ajaran syari'at Islam yang tertuang dalam Al Qur'an dan hadits Nabi agar terbentuk manusia yang dapat berperan sebagai hamba Allah yang setia di dalam segala aktivitasnya, sehingga tercipta suatu kondisi kehidupan yang Islami, bahagia, aman, sejahtera, dan berkualitas serta memperoleh kesejahteraan hidup di dunia dan keselamatan bagi kehidupan di akhirat kelak (Jalaluddin, 2001: 74). Pendidikan Islam oleh Marimba dipahami sebagai bimbingan jasmani dan rohani berdasarkan hukum-hukum agama Islam menuju pada terbentuknya kepribadian utama menurut ukuran Islam. Pengertian tersebut sangat jelas bahwa pendidikan Islam diartikan sebagai bentuk bimbingan terhadap jasmani dan sekaligus rohani yang menggunakan aturan menurut hukum agama Islam menuju terbentuknya karakter dan kepribadian yang mulia menurut Islam (Shofan, 2004: 49).

Antony mengutip pendapat Soekarno dan Supardi dalam Shofan mengartikan pendidikan Islam sebagai pendidikan yang berasaskan ajaran agama Islam. Sehingga maksud dari pendidikan Islam adalah usaha membina dan membentuk pribadi-pribadi muslim yang bertakwa kepada Allah, melahirkan generasi yang cinta dan kasih kepada kedua orang tua dan sesamanya, loyal terhadap tanah air, memiliki kemampuan dan kesanggupan memfungsikan potensi-potensi dalam dirinya dan alam sekitarnya. (Antony, 2016: 47) Dari pengertian tersebut dapat dipahami bahwa dasar utama pendidikan Islam adalah yang sesuai dengan apa yang tercantum dalam al quran dan hadits. Sehingga nilai positif secara rasional jika bertentangan dengan penjelasan dalam al quran dan hadits maka mendahulukan arahan dan anjuran yang terdapat dalam al quran dan hadits.
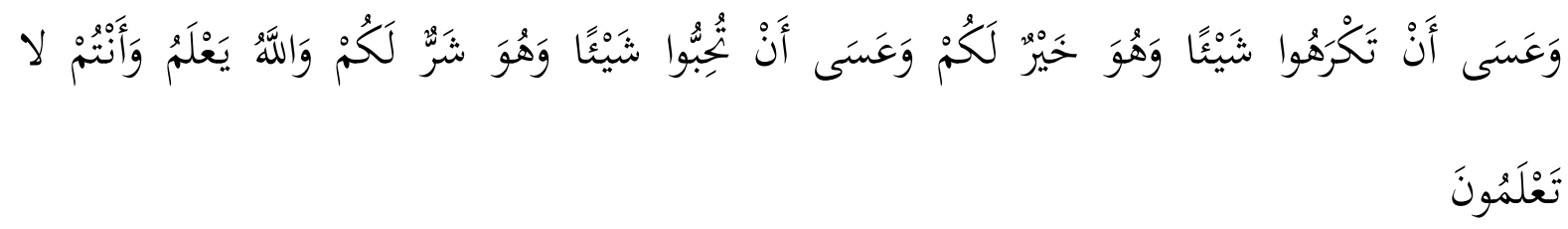

216. boleh Jadi kamu membenci sesuatu, padahal ia amat baik bagimu, dan boleh Jadi (pula) kamu menyukai sesuatu, padahal ia amat buruk bagimu; Allah mengetahui, sedang kamu tidak mengetahui (QS Al Baqarah 216). 
ZAHRA: Research And Tought Elmentary School Of Islam Journal Vol. (1) (2), (Agustus)(2020), (Halaman)(68-77)| 71

\section{Konsep Pendidikan Agama Islam}

Banyak tawaran konsep pendidikan Agama Islam yang disampaikan oleh para tokoh Muslim. Konsep tersebut tidak lain juga hasil dari analisa terhadap dakwah Nabi. Kedatangan Nabi pembawa ajaran Agama Islam tidak lain juga mendidik, menyampaikan materi kebenaran dan juga membentuk karakter. Hal tersebut adalah bagian dari ruh pendidikan. Ibnu Khaldun diantaranya yang konsep pendidikan yang banyak dikutip para penulis. Di dalam konsep pendidikan Khaldun, proses belajar mengajar memiliki beberapa ketentuan pokok sebagai acuan yang tidak boleh diabaikan. Setidaknya ada tujuh prinsip utama yang dikemukakan Ibnu Khaldun yang perlu diperhatikan, ialah;

1. Prinsip berangsur-angsur

Prinsip ini sesuai dengan ajaran diturunkannya wahyu pembawa hukum syariat kepada beliau nabi yang juga mengalami proses berangsur.

2. Prinsip pengenalan umum sebelum penjelasan (generalistik)

Langkah tersebut dilakukan agar siswa bisa menangkap materi dengan pemahaman yang mudah, baru kemudian dijelaskan lebih mendalam, maka bbuutuh untuk dijelaskan rincian dan pemahamannya.

3. Prinsip kontinuitas

Sebagai usaha untuk mencapai pemahaman secara kaffah. Karena tidak mungkin untuk memahami ajaran agama Islam hanya dengan beberapa kali pertemuan, sehingga membutuhkan jenjang yang terus berkelanjutan.

4. Memperhatikan bakat dan kemampuan peserta didik

Hal serupa juga disampaikan oleh al Ghozali dalam Antony Putra (2016; 50-52) bahwa kurikulum sebagai alat pendidikan harus disesuaikan dengan perkembangan anak didik. Dalam kitab Fath Bari disampaikan;

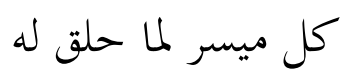

Setiap sesuatu dimudahkan sesuai dengan untuk apa sesuatu tersebut diciptakan. (Ibnu Hajar TT, 13/521).

5. Tidak mencampur materi yang bisa menjadikan bingung (concertie method/metode pemusatan)

Tugas sebagai pengajar harus mampu membaca kebutuhan siswanya, sehingga bisa memberikan sesuatu sesuai kebutuhan dan kemampuan. Diantara tujuan pembelajaran adalah memahamkan, untuk bisa memahamkan harus menghindari perkara yang membingungkan.

6. Menghindari kekerasan

Maksud dari menghindari kekerasan disini bukan berarti memberikan kebebasan dan kelonggaran terhadap anak didik. Sangsi atas kesalahan yang dilakukan anak didik bisa saja diberikan untuk menimbulkan efek jera, sebatas anak sudah menyadari kesalahan dan berusaha untuk lebih baik. "Perintahkan anak-anak kalian shalat pada usia 7 tahun, pukullah mereka jika 
ZAHRA: Research And Tought Elmentary School Of Islam Journal Vol. (1) (2), (Agustus)(2020), (Halaman)(68-77)| 72 meninggalkannya pada usia 10 tahun dan pisahkan di antara mereka tempat tidurnya." (HR. Ahmad dan Abu Dawud, dihasankan oleh An Nawawi dalam Riyadhus Shalihin)

7. Menumbuhkan skill

Untuk menumbuhkan skill peserta didik tidak cukup dengan faham dan hafal kaidahkaidah ilmiyahnya, namun dengan cara sering mengulang dengan memperbanyak contoh dan pembiasaan (Khaldun; tt, 648). Pembiasaan dan skill yang terbentuk dalam diri seseorang akan melahirkan citra rasa yang Islami. Hal ini terbukti dengan adanya legalitas tradisi masyarakat muslim yang bisa dijadikan sebagai penentu hukum atau kebijakan, jika tidak ditemukan dalil dalam al quran dan hadits.

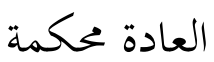

Tradisi itu dijadikan penentu hukum atau kebijakan. Dasar kaidah tersebut adalah hadits nabi

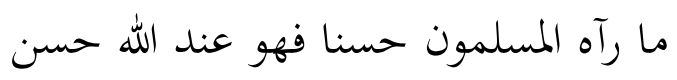

Sesuatu yang menurut orang-orang muslim baik, maka bagi Allah sesuatu itu juga baik (As Suyuthi, 1/128). Nahlawi memberikan konsep kurikulum dalam pembelajaran. Menurut Nahlawi, kurikulum merupakan suatu program bagi suatu jenjang sekolah dalam suatu lingkungan sekolah tertentu yang mencakup masalah metode, tujuan, tingkatan pengajaran, materi pelajaran setiap tahun ajaran, topik-topik pelajaran serta aktivitas yang dilakukan setiap siswa pada setiap materi palajaran yang disesuaikan dengan tahapan perkembangan dan kesiapan siswa. Maka kurikulum Islami harus memenuhi beberapa ketentuan:

a. Kurikulum islami harus memiliki sistem pengajaran yang bisa memelihara dan menjaga fitrah manusia dari penyimpangan.

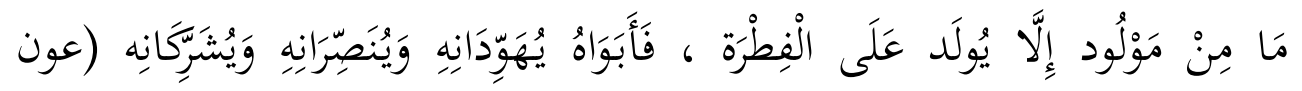

$$
\text { (المعبود) }
$$

Tidak ada dari setiap yang dilahirkan kecuali dilahirkan dalam keadaan fitrah, maka kedua orangtuanya yang menjadikannya yahudi, menjadikannya nasrani dan menjadikannya musyrik (Abu Thoyyib, tt: 10/230).

b. Kurikulum hendaknya diuraikan untuk mencapai tujuan akhir pendidikan Islam yaitu ikhlas, taat, dan beribadah kepada Allah,

$$
\text { وما خلقت الجن والانس الا ليعبدون }
$$


ZAHRA: Research And Tought Elmentary School Of Islam Journal Vol. (1) (2), (Agustus)(2020), (Halaman)(68-77)| 73 dan aku tidak menciptakan jin dan manusia melainkan supaya mereka mengabdi kepadaKu (QS Adz Dzariyat, 56).

c. Memperhatikan periodesasi perkembangan peserta didik maupun urisitas (kekhas-an) nya. Dalam kitab Fath Bari disampaikan;

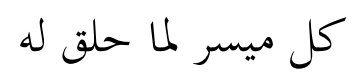

Setiap sesuatu dimudahkan sesuai dengan untuk apa sesuatu tersebut diciptakan (Ibnu Hajar TT, 13/521)

d. Teks kurikulum Islam harus memperhatikan tujuan-tujuan masyarakat yang realistis, dan bertitik tolak dari keislaman yang ideal.

e. Sistem kurikulum islami harus terbebas dari kontradiksi, selaras dengan integritas psikologis yang telah Allah ciptakan untuk manusia serta selaras dengan kesatuan pengalaman yang hendak diberikan kepada anak didik

f. Kurikulum Islami hendaknya realistik, yakni dapat diterapkan sesuai dengan situasi dan kondisi. Hal ini selaras dengan nafas syariat Islam yang sholihun fi kulli zaman wa makan, sesuai dalam setiap waktu dan tempat.

g. Hendaknya metode pendidikan atau pengajaran dalam kurikulum itu dapat disesuaikan dengan berbagai kondisi dan situasi kemampuan siswa setempat. Dalam Al Qur'an, Allah tidak membebani seseorang melainkan sesuai dengan kesanggupannya

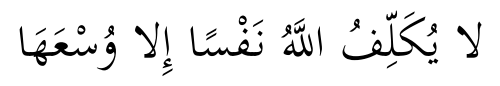

Allah tidak membebani seseorang melainkan sesuai dengan kesanggupannya (QS Al Baqoroh, 286).

h. Hendaknya kurikulum itu efektif. Dalam konsep Khaldun disampaikan tidak mencampur materi yang bisa menjadikan bingung (concertie method/metode pemusatan)

i. Memperhatikan tingkat perkembangan siswa yang bersangkutan.

j. Hendaknya kurikulum memperhatikan aspek-aspek tingkah laku amaliah Islami untuk membangun masyarakat muslim di lingkungan pendidikan (Abdul Aziz; 2009, 163)

Terdapat beberapa poin yang berhubungan dengan proteksi dini anak terhadap sisi negatif media sosial, baik pada konsep Ibnu Khaldun maupun konsep Nahlawi. Terlepas dari masing-masing kebijakan lembaga atau orang tua terhadap anaknya yang sama-sama memiliki sisi positif dalam mensikapi maraknya media sosial, tentunya pertimbangan yang paling utama adalah mengukur mana yang paling maslahah dan mana yang paling beresiko. Dalam penanganan yang berhubungan dengan penggunaan media sosial, setidaknya terdapat empat kebijakan; memberikan kebebasan penuh, memberikan kebebasan dalam pengawasan, memberikan kesempatan yang terbatas dan melarang sepenuhnya media sosial. 
ZAHRA: Research And Tought Elmentary School Of Islam Journal Vol. (1) (2), (Agustus)(2020), (Halaman)(68-77)| 74

Setiap kebijakan tersebut tentu telah melewati proses perencanaan dengan mempertimbangkan nilai-nilai positif. Sehigga tidak bisa sepenuhnya dianggap salah dan juga belum tentu bisa dipastikan benar. Karena membutuhkan pembuktian hasil yang dicapai selama proses pelaksanaan. Disinilah pentingnya evaluasi dalam pembelajaran.

1. Memberikan kebebasan penuh

Kebijakan yang satu ini adalah kebijakan yang paling beresiko. Namun tidak berarti ketentuan hukumnya harus dilarang, karena masih ada nilai positif dan kebaikan yang bisa didapatkan. Sehingga pertimbangannya adalah, jika resiko atau nilai negatif yang lebih dominan dihasilkan maka melarang adalah langkah yang menyelamatkan. Disaat tertentu, terkadang keadaan menuntut seseorang harus terjun di dalam media sosial. Karena bagaimanapun juga untuk membenahi dan melawan kemungkaran, tidak mungkin jika tidak mengenal dan tidak terjun dalam area tersebut. Orang-orang yang bisa mengendalikan keadaan kemungkaran yang boleh terjun ke dalamnya untuk membenahi dan mengambil sisi positif yang bercampur dengan nilai negatifnya, tidak setiap orang diperkenankan.

Bagaimana dengan siswa dan anak-anak yang masih labil psikologinya dan hawa nafsunya. Tentu sebagai orang yang memiliki tanggungjawab harus berpijak pada maslahah dalam mengambil dan memutuskan kebijakan.

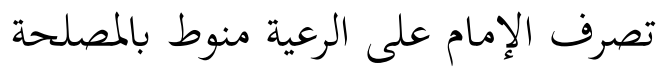

Kebijakan imam terhadap masyarakatnya harus berdasarkan maslahat (as Suyuthi, tt; 1/233). Spikulasi dalam mengambil kebijakan, atau membiarkan siswa atau anak terjun dalam lingkungan yang tidak dibekali dengan keahlian dan karakter baik yang sudah terbentuk dalam kepribadian untuk menjaga diri adalah larang dalam agama, sesuai dengan firman Allah

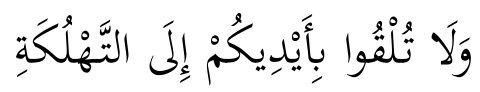

dan janganlah kamu menjatuhkan dirimu sendiri ke dalam kebinasaan (QS Al Baqarah, 195). Dengan demikian untuk kebijakan yang pertama ini lebih cenderung banyak mendatangkan sisi negatifnya daripada sisi positifnya, kecuali hanya untuk orang-orang tertentu.

2. Memberikan kebebasan dalam pengawasan.

Di dalam kebijakan yang ini, ukuran utamanya adalah kesiapan pengawas untuk selalu mengawasi yang bersangkutan. Berat ringannya pengawasan mempunyai hubungan dengan yang diawasi. Sehingga perlu adanya keseimbangan diantara keduanya. Secara rasional, tidak mungkin seseorang akan selalu bisa mengawasi orang lain, karena sudah tentu suatu saat memiliki kegiatan atau kepentingan yang berbeda. Bahkan bisa jadi kesempatan waktu memberikan pengawasan akan lebih sedikit dari pada waktu memberikan kebebasan, apa lagi yang dilakukan adalah pengawasan terhadap banyak siswa. Sehingga kebijakan yang kedua ini bukan 
ZAHRA: Research And Tought Elmentary School Of Islam Journal Vol. (1) (2), (Agustus)(2020), (Halaman)(68-77)| 75 pengawasan yang berperan dan bisa diharapkan dalam mengontrol pengaruh negatif media sosial, namun lebih pada ilmu dan karakter baik yang sudah terbentuk dalam kepribadian.

Kebijakan yang kedua ini lebih cenderung banyak mendatngkan sisi negatifnya daripada harapan mendapatkan sisi positifnya. Sama seperti kebijakan yang pertama. Hanya untuk orangorang tertentu yang bisa diharapkan mendapatkan banyak sisi positifnya.

3. Memberikan kesempatan yang terbatas.

Pembatasan kesempatan pada dasarnya adalah untuk memudahkan pengawasan. Dengan demikian kebijakan yang satu ini tidak jauh berbeda dengan kebijakan yang kedua, intinya adalah pengawasan. Hanya saja kebijakan yang ini lebih memungkinkan dan lebih bisa diharapkan siswa dan anak-anak bisa dikontrol hanya untuk mendapatkan sisi positif dari media sosial yang ada di tangannya.

Tidak kalah penting untuk diperhatikan adalah kesempatan-kesempatan kecil, peluang bisa mengakses nilai-nilai negatif disela-sela keteledoran pengawasan bisa berpengaruh menumbuhkan rasa penasaran untuk bisa mengenal lebih dalam. Sehingga akan memunculkan sikap mencuri kesempatan. Selama kehawatiran tersebut bisa disikapi, maka sisi negatif media sosial bisa dihindari. Namun jika kemampuannya masih diragukan, maka sebaiknya tidak mengambil resiko, artinya lebih baik memilih kebijakan yang keempat.

Kebijakan yang ketiga ini sangat tergantung dengan kedisiplinan pengawas. Dibutuhkan kesungguhan dalam kesiapan melakukan pengawasan. Keraguan atas kemampuan melakukan pengawasan secara intens

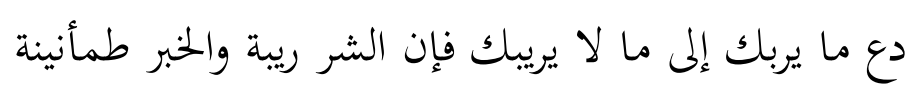

Tinggalkan sesuatu yang meragukan dirimu menuju sesuatu yang tidak meragukan dirimu, sesungguhnya keburukan adlah keraguan dan kebaikan adlah ketenangan (Abu Bakar, tt; 5/52)

4. Melarang sepenuhnya media sosial.

Pilihan kebijakan yang keempat ini adalah pilihan yang paling aman dari resiko, namun pilihan ini juga tidak mendapatkan manfaat atau nilai positif yang terdapat di dalamnya. Selama bentuk ketentuan kebijakan yang lain tidak bisa terpenuhi, maka kebijakan yang keempat ini adalah satu-satunya solusi. Melarang sama sekali menggunakan media sosial adalah langkah yang terbaik, meskipun tidak mendapatkan manfaatnya, nilai-nilai pembelajaran di dalamnya.

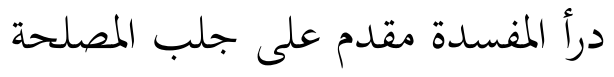

Menolak kerusakan diutamakan daripada menarik kemaslahatan

Meskipun terjadi sesekali siswa atau anak-anak melanggar dan memanfaatkan media sosial, namun jika berawal dari bentuk larangan tentu cara penggunaannya juga tidak terdapat kenyamanan, sehingga resikonya tetap lebih sedikit dibanding dengan adanya kebebasan. 
ZAHRA: Research And Tought Elmentary School Of Islam Journal Vol. (1) (2), (Agustus)(2020), (Halaman)(68-77)| 76

Dari paparan diatas dapat dikaitkan dengan konsep pendidikan Islam bahwa; termasuk salah satu faktor konsep pemikiran al Ghozali dalam pendidikan adalah menjaga pergaulan yang tidak baik, dengan teman atau lingkungan karena lingkungan yang jelek akan mempengaruhi perkembangan anak didik, terutama dilingkungan keluarga, sekolah atau masyarakat, (Antony Putra 2016: 50-52). Teman yang baik akan bisa saling mengisi dan mengingatkan dalam kebaikan, memberikan efek malu jika kita mau berbuat keburukan, memotifasi untuk bisa menjadi lebih baik dan meraih mimpi. Demikian juga sebaliknya, teman yang buruk akan bisa saling mengisi dan melengkapi dalam kejahatan, mendukung dan memotifasi untuk terus berbuat jahat. Sehingga besar sekali pengaruhnya teman dan lingkungan dalam membentuk karakter.

Dalam perkembangan sekarang pergaulan tidak harus diartikan dengan bertemu, berkumpul atau bermain bersama-sama dengan teman-teman, namun akses media sosial yang bisa kemana saja, bertemu dengan siapa saja, kapan dan dimanapun berada adalah bentuk dan cara pergaulan di era digital. Lengkapnya fitur dalam media sosial adalah bagaikan teman dan lingkungan yang bisa dipilih sebagai teman komunikasi atau teman bermain. Lepasnya pengawasan dari siapapun dalam memilih fitur yang terdapat dalam media sosial memberikan potensi besar terjadinya pilihan yang tidak benar. Tidak ada yang melarang, tidak ada rasa malu, tidak ada memperingatkan. Sehingga peringatan para ulama' terdahulu dalam memilih teman mestinya juga peringatan bagi kita dalam penggunaan media sosial.

Anak-anak yang masih labil dalam menentukan kemaslahatan dan masih lemah dalam mengendalikan nafsu tentunya masih belum saatnya untuk diberi peluang kebebasan dalam menggunakan media sosial. Konsep pendidikan Ibnu Khaldun maupun Nahwali juga mempertimbangkan tingkat kesiapan siswa dan kesesuaian materi atau media yang disiapkan.

\section{Simpulan}

Perlindungan terhadap anak dari pengarus sisi negatif penggunaan media sosial di masa pesatnya kemajuan teknologi tidak boleh diabaikan. Masing-masing lembaga pendidikan terhadap siswanya atau masing-masing orang tua terhadap anak-anaknya memiliki kebijakan tersendiri dalam melindungi anaknya. Jenis dan bentuk kebijakan yang berbeda-beda masing-masing memiliki sisi kelebihan dan sisi kekurangan. Keahlian pihak pimpinan lembaga ataupun orang tua memiliki peran penting dalam menentukan kebijakan yang sesuai dengan siswa atau anaknya. Pilihan kebijakan yang tepat akan menyelamatkan siswa atau anak dari resiko pengaruh negatif yang ditimbulkan oleh media sosial.

Terdapat empat bentuk kebijakan dalam mensikapi penggunaan media sosial, memberikan kebebasan penuh, memberikan kebebasan dalam pengawasan, memberikan kesempatan yang terbatas dan melarang sepenuhnya media sosial. Dari empat kebijakan tersebut, yang paling aman dari pengaruh negatif media sosial adalah melarang sepenuhnya, meskipun siswa atau anak-anak tidak 
ZAHRA: Research And Tought Elmentary School Of Islam Journal Vol. (1) (2), (Agustus)(2020), (Halaman)(68-77)| 77 mendapatkan manfat dari media sosial tersebut, yaitu sebagai media pembelajaran. Apalagi dimasa pertumbuhan anak yang masih lemah dalam mengendalikan hawa nafsu dan masih labil dalam menentukan nilai maslahat bagi dirinya.

\section{Daftar Pustaka}

Abu Thoyyib, Muhammad Syamsul Haqq, Aunul Ma 'bub, (Maktabah Syamilah)

Jalaluddin, as Suyuthi, Al Asybah wan Nadhair, (Maktabah Syamilah)

Ibnu Hajar, Fath Bari, (Maktabah Syamilah)

Aziz, Abdul. 2009. Filsafat Pendidikan Islam. Yogyakarta: Teras.

Putra, Ary Antony. 2016. Konsep Pendidikan Agama Islam Perspektif Imam Al- Ghazali. Jurnal AlThariqah Vol. 1, No. 1, Juni.

Creswell, John W. 2013. Penelitian Kualitatif \& Desain Riset. Yogyakarta: Pustaka Pelajar.

Jalaluddin. 2001. Theologi Pendidikan. Jakarta: PT Raja Grafindo Persada.

Shofan, M. 2004. Pendidikan Berparadigma Profetik Upaya Konstruktif Membongkar Dikotomi Sistem Pendidikan Islam. Yogyakarta: Ircisod.

Abu bakar, Ahmad, Syu’bul Iman, (Maktabah Syamilah) 